\title{
Między twórczością, edukacją a wychowaniem. Miejsce relaksacji w praktyce pedagogicznej
}

\begin{abstract}
Abstrakt
Szybkie tempo życia oraz zmierzenie się z aktualnym dylematem społecznym „mieć czy być" generują sytuacje stresowe u młodych ludzi, od których oczekuje się sprostania wymaganiom i oczekiwaniom współczesności. Autorki w obliczu tych wyzwań poddają refleksji miejsce oraz znaczenie efektywnego odprężania się w procesie edukacji i wychowania. Zaprezentowany przekrój terminologiczno-koncepcyjny został zbudowany w oparciu o analizę dostępnej literatury naukowej, dydaktycznej oraz popularnonaukowej. Dla wzbogacenia przedstawianych treści poczyniono rozpoznanie wśród nauczycieli, wychowawców oraz praktykujących studentów pedagogiki. Celem poniższych rozważań jest symboliczne „zaproszenie do dyskusji” na temat roli oraz wartości relaksacji w przestrzeni edukacyjno-wychowawczej. Autorki dokonują próby scharakteryzowania podstawowych metod relaksacyjnych, ukazując je na tle innych, bardziej popularnych w dyskursie nauki i praktyki, aktywności arteterapeutycznych. Ostatecznie prezentują szkic własnej propozycji metodycznej jako przykład elastycznego oraz twórczego wykorzystania zastanych technik.
\end{abstract}

Słowa kluczowe: relaksacja, relaks, wychowanie, edukacja, twórczość, zagrożenia cywilizacyjne, stres.

\section{Between creativity, education and upbringing. A place of relaxation in pedagogical practice}

\begin{abstract}
The fast pace of life and confronting the current social dilemma "to have or to be" generate stressful situations for young people who are expected to meet the demands and expectations of modern times. The authors reflect on the place and importance of effective relaxation in the process of education and upbringing. The presented terminological and conceptual cross-section was based on the analysis of available
\end{abstract}

* Uniwersytet Łódzki, Wydział Nauk o Wychowaniu, Pracownia Pedagogiki Specjalnej. 
scientific, didactic and popular science literature. To enrich the presented content, a reconnaissance was made among teachers, educators and students of pedagogy. The aim of the following considerations is a symbolic "invitation to the discussion" on the role and value of relaxation in the educational space. The authors attempt to characterize the basic methods of relaxation, displaying them against the background of art-therapy activities, more popular in the discourse of science and practice. Finally, they present a sketch of their own methodological proposal as an example of flexible and creative use of the existing techniques.

Keywords: relaxation, relax, education, creativity, civilization threats, stress.

\section{Wprowadzenie. 0 przemianach, zagrożeniach i wyzwaniach}

Nie ulega wątpliwości, iż istnieje ścisły związek pomiędzy wychowaniem a kulturą. Człowiek w procesie socjalizacji pierwotnej, a następnie wtórnej interioryzuje wartości oraz normy, które stanowią zaplecze do prawidłowego pełnienia ról społecznych. „Samodzielna aktywność” w społeczeństwie wymaga wiedzy oraz kompetencji umożliwiających nadążanie za przemianami społeczno-kulturowymi. Wychowując się w systemie pewnych wartości, człowiek wrasta w kulturę, stając się jej wyznacznikiem oraz propagatorem. Nie od dziś poddawany jest dyskusji narastający kryzys tradycyjnych (zwyczajowych) wartości, wypieranych przez nowoczesne trendy, głównie wypracowane przez młode pokolenie (Internet, język, muzyka, media itp.) (por. Szkudlarek 1999: 16-25). Zachodzące przemiany na gruncie kultury, gospodarki, techniki oraz nauki zmuszają do negocjacji obecności dotychczasowej hierarchii wartości na rzecz przeformułowanego ładu społecznego, dostosowanego do permanentnych zmian wpisanych w codzienne życie człowieka. Szybkie tempo oraz szeroka oferta dostępnych możliwości rozwoju z jednej strony motywują do działania, z drugiej zaś mogą przytłaczać i paraliżować, a towarzyszące poczucie „niewykorzystania wszystkich dostępnych na rynku szans” może być przyczyną złego samopoczucia. Zagrożeniem ciągłego antycypowania przyszłości jest zatracanie teraźniejszości. Dominujące we współczesnym społeczeństwie wartości nastawione na materializm, konsumpcję oraz komercjalizm zobowiązują pedagogów, psychologów oraz nauczycieli do dyskusji na temat wychowywania oraz kształtowania w młodym człowieku potrzeby respektowania tradycyjnych wartości w „nowym” współczesnym ładzie społecznym.

Największymi czynnikami stresogennymi dla młodego człowieka jest życie rodzinne, szkolne oraz rówieśnicze. Dodatkowo czynnikami potęgującymi długotrwały stres mogą być indywidualne konstrukcje psychiczne, jak: niski poziom samooceny, brak wiary w siebie, kompleksy (Przetacznik-Gierowska 2018: 64). Trudności szkolne są najczęściej doświadczanym stresorem w grupie nastolatków (por. Jelonkiewicz, Kosińska-Dec 2004; Mularska 2001; Witkin 2000). Czynnikami stresogennymi są przede wszystkim obowiązki szkolne oraz relacje z nauczyciela- 
mi, tj. klasówki, sprawdziany, konflikty, zmiana szkoły, oceny, wyzwania, krytyka. Badania prowadzone przez Elżbietę Talik wykazały, iż młodzież doświadczająca silnego stresu szkolnego jest zorientowana na wypracowanie samodzielnego (indywidualnego) sposobu radzenia sobie z napięciem psychofizycznym. W obliczu przeżywanego stresu nastolatkowie podejmują różne działania zaradcze, które mogą mieć dychotomiczne konsekwencje (Talik 2011: 127-130). Widoczne zaniedbania w przestrzeni edukacyjnej oraz brak programów profilaktycznych dotyczących problematyki stresu wymuszają na młodzieży poszukiwanie alternatywnych metod rozładowania napięcia psychofizycznego. Brak wiedzy oraz kompetencji w zakresie redukcji stresu może skutkować ryzykownymi oraz niebezpiecznymi zachowaniami. Dodatkowym generatorem potencjalnego zagrożenia jest okres adolescencji, w którym to następuje wzrost potrzeby doświadczania extremum. Do niepożądanych sposobów radzenia sobie ze stresem można zaliczyć labilność emocjonalną, autoagresję, używki, przemoc, podejmowanie ryzyka w cyberprzestrzeni, niezdrową dietę i wiele innych (por. Komorowska 2008; Ogińska-Bulik 2016; Tyszkowa 1986). Działania relaksacyjne mogą usprawnić proces edukacyjny i wychowawczy, redukując poczucie napięcia, stresu, lęku oraz potrzebę podejmowania ryzykownych zachowań. Martin Herbert uświadamia znaczenie okresu dorastania dla ludzkiej egzystencji, a także uwrażliwia profesjonalistów i rodziców na intensyfikację trudnych zachowań, wywołanych dynamicznymi zmianami rozwojowymi (Herbert 2004: 11-14). Szczególnie w przestrzeni edukacyjno-wychowawczej umiejętne i prawidłowe radzenie sobie ze stresem jest bardzo istotne.

Niezaprzeczalnie stres jest integralną częścią ludzkiego życia. Ewa Marynowicz-Hetka zwraca uwagę na rozumienie rozwoju w dwu wymiarach. Można mówić o rozwoju w momencie przyrostu zmian, a także należy pamiętać o istocie jakościowych przemian. Mogą one zachodzić dzięki świadomej aktywności człowieka, ponadto polegają na optymalizowaniu, a także udoskonaleniu istniejącego stanu. Istotą rozwoju jest szereg zmian prowadzących do intensyfikowania efektywności oraz jakości funkcjonowania człowieka na różnych płaszczyznach życia (Marynowicz-Hetka 2010: 10-11). Kategoria optymalnego rozwoju jest ściśle związana z procesem wychowania. Młody człowiek w poszukiwaniu swojej tożsamości jest narażony na wiele porażek i niepowodzeń, które są naturalnym elementem wpisanym w rozwój, dlatego wszelkie działania wychowawcze skierowane na ucznia/ wychowanka powinny mieć charakter holistycznych, przemyślanych i świadomych decyzji.

Jednym z efektów przemian cywilizacyjnych jest wzrastająca rola kultury mass mediów oraz społeczności wirtualnych. Życie online niesie ze sobą wiele możliwości oraz niebezpieczeństw, które przyczyniają się do kształtowania obecnego społeczeństwa. Rozwój społeczności internetowej virtual community skutkuje dyfuzją kultur, która może mieć dychotomiczne następstwa dla równowagi rozwoju młodego człowieka. Nieodłącznym elementem webkultury jest bycie in touch, 
followanie oraz lajkowanie zdjęć i postów swoich znajomych na portalach społecznościowych. Negatywnym wymiarem eksplorowania Internetu jest cyberbullying, uzależniające i niebezpieczne challenge oraz fałszywe kreowanie swojego internetowego wizerunku. Niedoścignione, idealne życie w social media nierzadko generuje frustracje oraz złość wśród nastolatków (por. Olechnicki 2009; Daszykowska 2009; Pyżalski 2012). Ponadto ofiary cyberprzemocy odczuwają stres przejawiający się strachem, złym samopoczuciem, niechęcią do szkoły, a nawet myślami samobójczymi (Pracojło-Maj 2015: 94-100). Jerzy Nikitorowicz (2003: 65) wskazuje, że „współczesny człowiek coraz częściej wydaje się niezadowolony z ról świata rzeczywistego i podejmuje próby kreowania samego siebie w świecie wirtualnym, w którym nie musi ponosić odpowiedzialności za swoje zachowania i czyny, a może otrzymać natychmiastową gratyfikację".

Dodatkowym stymulatorem pojawienia się złego samopoczucia mogą być zmiany hormonalne, które są charakterystyczne dla okresu dojrzewania. Nieprawidłowe radzenie sobie ze stresem oraz wymuszone wygaszanie napięcia mogą prowadzić do zachowań ryzykownych, a także trudności wychowawczych. Nieefektywne radzenie sobie ze stresem może być wynikiem indywidualnych różnic charakterologicznych, odporności emocjonalnej oraz wyuczonych nawyków odprężania i relaksacji. Uzależnienia behawioralne mogą być odpowiedzią na stresory życia codziennego. Brak wypracowanego prawidłowego mechanizmu redukcji napięcia psychofizycznego może prowadzić do nałogów, które tylko pozornie przywracają równowagę emocjonalną. W momencie pojawienia się sytuacji stresowej człowiek dokonuje oceny pierwotnej (określenia zdarzenia jako pozytywne, neutralne lub negatywne). Negatywna sytuacja wyzwala stres powodujący reakcje emocjonalne i określone zachowania. W tym momencie następuje proces oceny wtórnej sytuacji stresującej. Zostają poddane analizie wszelkie zasoby, potencjały, kompetencje oraz możliwości człowieka pozwalające na radzenie sobie z czynnikiem stresującym. Autorzy zwracają uwagę na skłonność do zniekształceń przeżywanych wydarzeń i określania ich jako negatywnych. Efektem takiej oceny może być samospełniające się proroctwo (prowadzące do depresji, przygnębienia, obniżenia poczucia własnej wartości) lub ucieczka w używki (alkohol, narkotyki, papierosy, seks, hazard) (por. Heszen 2013; Baduń-Korulczyk 2013; Lazarus 1986).

Jeżeli działania relaksacyjne skierowane na młodych ludzi będą zaplanowane i przemyślane, mogą usprawnić proces edukacyjny i wychowawczy, redukując poczucie napięcia, stresu, lęku oraz potrzebę podejmowania ryzykownych zachowań. Pedagodzy oraz nauczyciele powinni pamiętać o wartości, a zarazem konieczności relaksacji w przestrzeni edukacyjno-wychowawczej. Andrzej Szyszko-Bohusz (1979), prekursor badań efektów relaksacji, a także wprowadzania ćwiczeń odprężających, przeprowadził badania, które jasno wskazały potrzebę oraz znaczenie włączania działań relaksacyjnych do pracy z dziećmi i młodzieżą. Ponad 88\% uczniów szkoły podstawowej wykazało pozytywne nastawienie do aktywności 
odprężającej, a 75\% dzieci potwierdziło, że ćwiczenia relaksacyjne pomogły im w polepszeniu zachowania w szkole, a także poza terenem szkoły. Autorska propozycja konspektów zajęć o charakterze relaksacyjno-odprężającym może pomóc nauczycielom, pedagogom, terapeutom, psychologom, wychowawcom placówek resocjalizacyjnych, a także opiekuńczo-wychowawczych. Realizowanie zajęć relaksacyjnych może służyć celom diagnostycznym, prognostycznym, terapeutycznym oraz profilaktycznym.

\section{Inspiracje metodyczne. Przegląd wybranych metod}

Opisane w artykule typy działań relaksacyjnych stanowią jedynie kilka wyróżnionych przez autorki propozycji. Przede wszystkim nawiązują one do profesjonalnych praktyk ukierunkowanych na efektywne odprężanie się, jednocześnie uwzględniają twórczy aspekt działań pedagogicznych. Jedną z podstawowych propozycji jest tzw. relaksacja progresywna oparta na świadomym regulowaniu pracy swoich mięśni. W ramach treningów zaproponowanych przez dwóch prekursorów - Edmunda Jacobsona oraz Johannesa Schulza, jednostka (uczestnik praktyk) poddana relaksacji uczy się świadomego utrzymywania i doświadczania napięcia wraz z progresywnym, stopniowym rozluźnianiem napiętego ciała (Kulmatycki, Torzyńska 2013: 26-30). Metoda Jacobsona po raz pierwszy została opublikowana w 1929 r. Jej głównym założeniem jest rozluźnianie poszczególnych grup mięśniowych dla uzyskania bardziej ekonomicznego zużycia energii w czasie wysiłku fizycznego. Na drodze regulacji napięcia mięśniowego Jacobson skutecznie przeciwdziałał napięciom psychicznym. Z drugiej strony tzw. trening autogenny Schulza inspirowany był badaniami nad autohipnozą. Stanowi swoisty rodzaj gimnastyki psychicznej opartej na powtarzaniu autosugestywnych formuł (por. Kulmatycki, Torzyńska 2013; Szyszko-Bohusz 1979).

Kolejną grupę technik zorientowanych na relaksację stanowią działania oparte o szeroko rozumiane doznania zmysłowe, gdzie odprężenie następuje poprzez specyficzne, ukierunkowane obserwacje wrażeń płynących z otoczenia. Jak zauważa Cungi i Limousin „podczas obserwacji wrażeń dostarczanych przez organy zmysłu, myśli uspakajają się i podążają za odczuciami” (Cungi, Limousin 2010: 82). Do optymalizacji efektów prowadzi systematyczne i celowe wzbogacanie zakresu swoich zmysłowych doznań w wybranych obszarach. W przestrzeni doznań wzrokowych obserwator najczęściej wybiera jeden miły dla oka przedmiot, skupia na nim uwagę i zgłębia przyjemne odczucia. Obserwacja służy również docenianiu, a nawet niekiedy zauważaniu pozornie „neutralnych i obojętnych” obiektów (dostrzeganie obecności przedmiotów w otoczeniu i codzienności). W obserwacji zorientowanej na odprężenie świetnie sprawdzają się zarówno przedmioty codziennego użytku, jak i ciekawe fotografie czy wytwory sztuki o skomplikowanym poziomie estetyki. Z drugiej strony niemniej przydatne wydają się elementy dyna- 
miczne (ruchome). Odprężeniu szczególnie sprzyja doznawanie i posługiwanie się ruchem płynnym, harmonijnym i jednostajnym. W procesie relaksacji niemniej popularne staje się odbieranie i wytwarzanie różnego rodzaju dźwięków. Jedną z metod bazujących na doznaniach akustycznych jest tzw. zoomowanie dźwięków, czyli niezwykle uważne wsłuchiwanie się w odgłosy płynące z otoczenia, które na ogół nie są dostrzegane przez jednostkę. Te „dźwiękowe” tła pobudzają „uśpioną” percepcję słuchową. Ostatecznie warto wspomnieć o relaksacji osiąganej poprzez dotyk. Najpopularniejsze w tej przestrzeni stają się masaże relaksacyjne. Odbierane za pośrednictwem skóry bodźce pozwalają na osiągnięcie nowej jakości kontaktu ze światem i otoczeniem (Cungi, Limousin 2010).

Zdaniem autorek trudno jest wyznaczyć jednoznaczną granicę między metodami opartymi o doznania zmysłowe, a podstawowymi założeniami arte- i muzykoterapii. Choć propozycje terapeutyczne stanowią działania o specyficznych celach oraz na ogół odwołują się do uporządkowanych, utrwalonych założeń i tradycji pedagogicznych, przy odpowiedniej modyfikacji (skomponowaniu wybranych elementów i wzbogaceniu o zmysłowe formy działania) mogą przysłużyć się praktykom relaksacyjnym. Arteterapia (dokładnie arte- (łac.) sztuka oraz therapeuein (gr.) - leczenie) (Nowak 2008: 21) w szerokim znaczeniu stanowi zespół metod oraz form pomocy terapeutycznej, przy wykorzystaniu elementów sztuki, a także wszystkich form aktywności artystycznej (m.in. śpiew, taniec, malowanie, drama, literatura). W tym znaczeniu arteterapia jest traktowana jako komplementarna oraz wyspecjalizowana forma psychoterapii, gdzie wykorzystuje się wytwory sztuki do uzyskania poprawy kondycji psychicznej oraz fizycznej człowieka (Szulc 2012: 63-64). Warto zwrócić uwagę na wielofunkcyjność zastosowania arteterapii oraz przypisywaną jej funkcję korekcyjną, profilaktyczną oraz relaksacyjną (Gładyszewska-Cylulko 2007: 53). Zwiększa poziom samoakceptacji, samooceny oraz rozwija ekspresję i spontaniczność. Ponadto pozwala na wyrażanie własnych uczuć i emocji w różnych formach. Umacnia wiarę we własne siły, a także - co istotne, w kontekście relaksacyjnym - umożliwia uwalnianie się negatywnych emocji potęgowanych przez czynniki stresogenne (por. Marek 2004; Józefowski 2012). Badania nad wpływem sztuki na człowieka pozwoliły na wyodrębnienie kilku typów arteterapii, w tym m.in. arteterapię o charakterze czynnościowym, której celem jest uwolnienie człowieka od destrukcyjnych myśli; arteterapię o charakterze sublimacyjnym, umożliwiającą odreagowanie niepożądanych emocji; arteterapię o charakterze projekcyjnym, dającą przestrzeń do prezentacji uczuć i postaw; oraz arteterapię o charakterze korekcyjnym i integrującym, ukierunkowaną na aktywizację zdolności człowieka (Rozmysłowicz 2005). Za najczęściej wykorzystywane rodzaje arteterapii uznaje się: muzykoterapię, terapię z wykorzystaniem sztuk plastycznych, wizualnych, choreoterapię, biblioterapię, teatroterapię oraz filmoterapię (Konieczna 2013: 11). W odniesieniu do relaksacyjnych doznań zmysłowych nie sposób pominąć rolę muzykoterapii jako „przemyślanego i planowanego wykorzystywania muzyki i/lub jej elementów w ramach relacji terapeu- 
tycznej z dzieckiem lub nastolatkiem w celu odbudowania, podtrzymania i wspierania ich zdrowia psychicznego i somatycznego oraz korekcji i wspomagania rozwoju" (Stegemann, Hitzeler, Blotevogel 2013: 64). Muzykoterapia stała się metodą terapeutyczną ściśle powiązaną z pedagogiką, psychologią, a nawet muzykologią. Odwołując się do podstawowego rozróżnienia, należy wspomnieć o istnieniu dwu głównych typów muzykoterapii, tj. muzykoterapii receptywnej - zorientowanej na odbieranie bodźców dźwiękowych (najczęściej wykorzystywanej u boku technik relaksacyjnych) oraz aktywnej - opartej na wytwarzaniu dźwięków najczęściej $w$ postaci rozmaitych improwizacji. U młodych ludzi muzyka oprócz kształtowania tożsamości oraz umożliwiania identyfikacji odgrywa ważną rolę w regulacji emocjonalnej. Muzyka staje się pozajęzykową przestrzenią wyrażania własnych odczuć. Bodźce muzyczne mogą wywoływać liczne reakcje emocjonalne przekazywane przez ośrodki emocji (m.in. układ limbiczny, zakręt obręczy, prawy płat czołowy). Wpływ muzyki na jednostkę wiąże się zarówno z biopsychiką (neurobiologią), ale także uwarunkowaniami kulturowymi i autobiograficznymi (Konieczna 2013).

Ostatnią, szeroką i zróżnicowaną grupę technik relaksacyjnych stanowią praktyki o charakterze orientalnym, w której to możemy wyróżnić m.in. medytację, kontemplację oraz rozmaite warianty wizualizacji. Techniki kontemplacyjne i medytacyjne choć swoje źródła mają w praktykach religijnych, w procesie relaksacji służą poszerzaniu świadomości i twórczości w różnych wymiarach - fizycznej, etycznej, filozoficznej, poetyckiej etc. Kontemplację można zdefiniować jako specyficzne skupienie się na jakiejś ważnej myśli oraz konsekwentne powtarzanie jej. Na drodze kontemplacji jednostka dąży do wtopienia repetowanej myśli do umysłu (zatopienia się w sugerowanej treści). Medytacja ze względu na swój poziom skomplikowania staje się nie tylko metodą relaksacji, ale również samodoskonalenia (por. Kulmatycki 1995; Szulc 2012). W zachodniej kulturze do najpopularniejszych technik medytacyjnych zalicza się jogę i zen. Medytację można uprawiać również jako szczególną formę autopsychoterapii. W tym rozumieniu służy ona koncentracji na własnych procesach fizjologicznych, zmierzającej do uruchomienia innych modułów świadomości. Za nadrzędny cel stawia się uzyskanie stanu relaksu i odprężenia oraz rozwiązanie wewnętrznych konfliktów, w tym rozładowanie dawnych urazów, a także lepsze samopoznanie, wyzwalające ukryte potencjały (Siek 1990). W praktyce do osiągnięcia celu wykorzystuje się specyficzny rodzaj ćwiczeń gimnastycznych jogi, polegający na przyjmowaniu określonych pozycji ciała (tzw. asany). Asana jest nieruchomą, wybraną konfiguracją, w której wywiera się specjalny nacisk na narządy ciała i centra nerwowe. Zwykle towarzyszą tym figurom harmonijne ćwiczenia oddechowe, służące regulowaniu wentylacji. Stanisław Siek wyróżnił kilka sposobów praktykowania jogi (czynności medytacyjnych ukierunkowanych na odprężenie). Wśród nich warto wyróżnić: liczenie własnych oddechów - związane z nauką obserwacji całego procesu wentylacji, gdzie uczestnik zajęć monitoruje przepływ powietrza, koncentruje się na poszczególnych 
organach, które biorą udział w tym procesie; koncentracja na dawaniu odpowiedzi jako jedna z form medytacji zen, podczas której uczestnik koncentruje uwagę na swoistych zagadkach (tzw. paradoksie KOAN). Zagadki przyjmują formę pytań, na które nie można udzielić odpowiedzi; koncentracja na powtarzaniu mantry - oparta na repetowaniu słów, sylab, zdań, formuł; koncentracja na bodźcach wzrokowych - często realizowana poprzez wpatrywanie się w jeden statyczny przedmiot (tamże: 35-40).

Niemniej przydatna w przestrzeni relaksacji staje się wizualizacja - czyli w najprostszym ujęciu - tworzenie wyobrażeń w umyśle. Zakłada się, że świadome i aktywne sterowanie wyobraźnią, tj. przywoływanie w pamięci obrazów i zdarzeń zostaje utrwalone i przeniesione na inne sytuacje, a w efekcie służy odprężeniu. Wyobrażone obrazy rodzą uczucie przyjemności (źle dobrane mogą również rozbudzać lęk i panikę). Z łatwością można z tego skorzystać, np. w drodze do pracy, podczas przerwy szkolnej lub w innych dowolnych okolicznościach (por. Cungi, Limousin 2010: 101-103). W wizualizacji możemy mówić o dwóch typach tworzonych obrazów - ruchomych i nieruchomych. Nieruchome opierają się na doborze przedmiotów pięknych, przyjemnych i jednocześnie statycznych. Osoba praktykująca zachowuje nieruchome spojrzenie. Wraz ze wzrostem uczucia odprężenia następuje uwypuklenie wyobrażonego obrazu, zaś wizualizowany przedmiot staje się źródłem spokoju. Tworzenie obrazów ruchomych bazuje na płynnym przemieszczaniu wyobrażonego obrazu. Jednym z prekursorów metod wizualizacyjnych był Jose Silva. Z początku, w zamyśle twórcy metoda ta miała przyspieszać proces uczenia się. Jak podkreślał Silva - stosowanie metody dynamicznej (opartej o wizualizację) poprawia pamięć, ułatwia uczenie się, zwiększa zaufanie do siebie oraz podnosi samopoczucie (por. Cungi, Limousin 2010; Kulmatycki, Torzyńska 2013).

\section{W poszukiwaniu nowych rozwiązań. Propozycja autorska}

Podstawę własnych propozycji (implikacji dla edukacji i wychowania) stanowi kilkuetapowe rozpoznanie typów, popularności oraz przydatności działań relaksacyjnych w przestrzeni pedagogicznej. Na wstępie warto zaznaczyć, że w ramach podjętego projektu autorki nie zaplanowały żadnej sprecyzowanej procedury badawczej. Systematyczny przegląd dostępnej (polskiej) literatury przedmiotu stanowił bowiem bazę do stworzenia autorskiego opracowania poświęconego metodom efektywnego odprężania się w przestrzeni edukacyjnej i wychowawczej. Autorki skoncentrowały się na przeglądzie opracowań o charakterze metodycznym (tj. zwartych propozycji działań z uczniem/grupą) ${ }^{1}$. Autorki poddały dyskusji

\footnotetext{
1 Por. Sasin, Pikała, 2016; Baranowska-Jojko, Wiechuła, Fronczak 2018; Gładyszewska-Cylulko 2011; Sędłak, Wycech 2014; Kozdroń 2014; Furmanik-Celejewska 2016; Gąsienica-Szostak 2014; Konieczna 2010; Stegemann, Hitzeler, Blotevogel 2013; Zubrzycka-Maciąg 2016.
} 
atrakcyjność poszczególnych konspektów, analizując bogactwo proponowanych przez autorów ćwiczeń/warsztatów, przykładowe konspekty działań, adekwatność propozycji względem możliwości przestrzennych i czasowych placówek (m.in. prześledzono zakres niezbędnych materiałów, czas trwania poszczególnych ćwiczeń, wymagania dotyczące sali/miejsca etc.), a także wielość i zróżnicowanie propozycji adresowanych dzieciom i młodzieży². Ponadto na drodze pozyskiwania wiedzy autorki dokonały przeglądu dzienników praktyk studenckich. Rozpoznaniu poddano ponad 300 zapisów (tzw. dzienniczków) studentów realizujących swe praktyki w placówkach dedykowanych dzieciom i młodzieży (głównie szkołach, ośrodkach szkolno-wychowawczych, świetlicach terapeutycznych, młodzieżowych ośrodkach socjoterapii oraz młodzieżowych ośrodkach wychowawczych) w latach 2016-2018. Rozpoznanie to pozwoliło zauważyć, że w żadnym dokumencie (opisie podejmowanych przez studentów obserwacji oraz własnych aktywności) nie pojawiły się działania stricte ukierunkowane na relaks i odprężenie. Uboga oferta podręczników tematycznych oraz znacząca „niepopularność relaksacji” w praktykach studenckich przyczyniły się do podjęcia pracy nad stworzeniem przystępnych autorskich opracowań, wychodzących naprzeciw zagrożeniom, jakie niesie ze sobą nieumiejętność rozładowania napięć oraz negatywne skutki stresu. Autorska propozycja oparta jest na trzech typach warsztatów: Typ I „twardy”, Typ II „sensoryczny” oraz Typ III „miękki”3. Zróżnicowania dokonano ze względu na nadrzędny cel działań oraz dominujące inspiracje metodyczne, które stanowią podstawę opracowanych ćwiczeń. Na potrzeby artykułu autorki ograniczyły się jedynie do krótkiego naszkicowania podstawowych założeń teoretycznych. Głównym celem publikacji jest wzbudzenie refleksji na temat miejsca - a może nawet trafniej „nieobecności” działań relaksacyjnych w przestrzeni edukacyjnej i wychowawczej. Autorska propozycja została zreferowana głównie w celach inspiracyjnych, ukazując możliwości łączenia wybranych technik i kierunków. Stanowi niejako „zaproszenie" do podjęcia dalszych rozważań nad formami i potencjałami oddziaływań relaksacyjnych ${ }^{4}$.

Pierwszy zaproponowany zestaw (Typ I) zorientowany jest na wypracowanie obrony przed stresorami poprzez wpływanie na stresory. W projektowaniu ćwiczeń dominującą inspiracją stała się relaksacja neuromięśniowa fizycznie aktywna, w tym głównie ćwiczenia progresywne Jacobsona, trening autogenny Schulza oraz metody oparte o ćwiczenia oddechowe. Każdy zwarty konspekt złożony jest z kilku

\footnotetext{
2 Autorki w tym miejscu jedynie sygnalizują przyczynki powstawania autorskiej propozycji warsztatowej. Celowo rezygnujemy z dokładnego referowania i komentowania prac poszczególnych autorów. Nie poddajemy jakościowej ocenie przeanalizowanych propozycji działań.

3 Inspiracją do takiego podziału zaproponowanych typów konspektów był autorski model strategii antystresowej opracowany przez L. Kulmatyckiego (1993).

${ }^{4}$ Pełna charakterystyka trzech autorskich typów ćwiczeń wraz z załączonymi wskazówki metodycznymi oraz zbiorem konspektów stanowi podstawę opracowania zatytułowanego: Techniki $i$ metody relaksacyjne $w$ wychowaniu, edukacji i terapii. Scenariusze pracy z dziećmi i młodzieżą (publikacja w druku).
} 
pojedynczych ćwiczeń, opatrzonych motywem przewodnim. Zestawy zadań w I Typie mają najdynamiczniejszy charakter oraz częściej niż w pozostałych propozycjach bazują na działaniach zespołowych (praca grupowa, praca w parach). Oprócz redukcji napięcia uczestnicy mają możliwość doskonalenia swojej koordynacji ruchowej oraz elastyczności (sprawności fizycznej). Zestaw ćwiczeń uwzględniał przede wszystkim potencjały i możliwości najmłodszych grup uczestników (dzieci w wieku szkolnym).

Drugi typ zadań („sensoryczny”) zorientowany jest na wypracowanie obrony przed stresorami poprzez uodparnianie na stresory. Bazę stanowi relaksacja neuromięśniowa fizycznie bierna. Ćwiczenia opracowane w tym obszarze inspirowane są metodami opartymi o doznania sensoryczne oraz pracę z wyobraźnią i wizualizacjami. W konspektach skoncentrowano się głównie na wzbudzaniu wrażeń synestezyjnych oraz doskonaleniu odbierania i nazywania odczuwanych doznań.

Trzecip 3 (tzw. ćwiczenia „miękkie”) zorientowano na wypracowanie obrony przed stresorami poprzez dystansowanie się do stresorów. Warsztaty te mają najmniej dynamiczny charakter. Uczestnicy rzadko pracują w parach lub zespołowo. Przede wszystkim zmierzają do doświadczania własnej indywidualności oraz pogłębionej autorefleksji. Bazą stały się praktyki kontemplacyjne i medytacyjne, przy wykorzystaniu krótkich tekstów poetyckich. Głównym celem tego typu zajęć jest wpływanie na samopoczucie i samoakceptację. Zbiór konspektów opartych o ćwiczenia „miękkie” dedykowany jest najstarszym odbiorcom (młodzieży w wieku licealnym, a nawet osobom dorosłym).

Kluczowe w projektowaniu działań relaksacyjnych było ukierunkowanie na grupę przy jednoczesnym uwzględnieniu indywidualnych potencjałów, potrzeb oraz potencjalnych trudności. Proponowane formy ćwiczeń wymagają od prowadzącego wrażliwości oraz czujności umożliwiającej w razie potrzeby bieżące modyfikacje ćwiczeń. Należy pamiętać, iż każdy uczestnik ma prawo do decydowania o dystansie, jaki chce utrzymać, odstąpienia od aktywności w dowolnym momencie, zakomunikowania o odczuwanych trudnościach. Od prowadzącego wymaga się subtelności oraz wyczucia $w$ wychwyceniu pojawienia się ewentualnych trudności oraz oporu ze strony uczestników. Zaproponowany przez autorki podział konspektów na trzy typy umożliwia dostosowanie przebiegu realizacji do potrzeb i oczekiwań grupy. Ponadto elementem łączącym wszystkie trzy typy warsztatów stały się praktyki wizualizacyjne. Uczestnicy za pośrednictwem wybranych przedmiotów (wskazanych w tematach konspektów) niejako „oddalają się” od osobistych trosk. Porzucają „dziejącą się codzienność” na rzecz abstrakcyjnych wyobrażeń. Za pomocą tzw. „tekstów stymulacyjnych” wcielają się we wskazane przedmioty i motywy. W twórczy sposób kreują otoczenie oraz siebie w świecie. W konsekwencji poszczególne etapy działania prowadzą do stanu relaksu i odprężenia. Zatem relaksacja to proces, który ma na celu ogólne rozluźnienie ciała oraz umysłu, a także uwolnienie go od napięć psychofizycznych. Prezentowane zestawy ćwiczeń 
zakładają stymulację potencjału, wznoszenie świadomości oraz motywacji. Kompleksowe odprężenie psychofizyczne stanowi fundament do podjęcia współpracy z podopiecznym na różnych płaszczyznach. Zaproponowane konspekty zajęć można zrealizować w szkołach, przedszkolach, świetlicach, placówkach resocjalizacyjnych, opiekuńczo-wychowawczych oraz innych instytucjach, gdzie młodzi ludzie są narażeni na czynniki stresogenne.

\section{Aplikacja dobrych praktyk. Działania pilotażowe}

Opracowane konspekty zostały wykorzystane podczas warsztatów tematycznych realizowanych z ramienia Naukowego Koła Resocjalizacji UŁ. Działania te - jak już wspominano - nie miały charakteru badawczego. W oparciu o powstałe scenariusze zajęć autorki dokonały pilotażowych prezentacji w formie warsztatów tematycznych zorientowanych wokół znajomości metod i technik relaksacyjnych w przestrzeni pedagogicznej. Spotkania przyjęły formę wykładową i ćwiczebną. Warsztaty praktyczne poprzedzone były krótkimi wykładami tematycznymi, obejmującymi problematykę stresu i relaksacji. Realizacja warsztatów wdrożeniowych i spotkań tematycznych miała charakter cykliczny, odbywała się na przestrzeni 8 miesięcy. W zajęciach brali udział zarówno studenci pedagogiki, jak i aktywni wieloletni praktycy (m.in. przedstawiciele organizacji pozarządowych działający na rzecz wzmacniania sektora edukacji, a także wychowawcy i nauczyciele szkół oraz placówek resocjalizacyjnych). Rozmowy (wykłady) połączone zostały z warsztatami praktycznymi (realizacją i prezentacją wybranych konspektów), dzięki czemu uczestnicy mogli wyrazić własną opinię na temat propozycji. Niezwykle cenne stały się uwagi pozwalające na udoskonalenie pomysłów (nie tylko strony merytorycznej, ale również technicznej). Koncentrując się na wybranych ćwiczeniach (zadaniach), omówione zostały potencjalne grupy docelowe, optymalny czas realizacji zajęć, dobór narzędzi i pomocy (np. muzyki, akcesoriów), a także inne warunki organizacyjne. Sposób pozyskiwania opinii przebiegał drogą półformalną, co oznacza, że autorki celowo nie opracowały zwartej procedury badawczej. Na podstawie zgromadzonych notatek (opartych na weryfikacji literatury, dzienników praktyk oraz opinii pozyskanych w ramach warsztatów) autorki zwróciły uwagę na trzy podstawowe problemy zasługujące na szczególną refleksję: 1) brak znajomości technik relaksacyjnych zarówno wśród studentów, jak i praktyków, 2) uboga, mało urozmaicona propozycja gotowych narzędzi w postaci konspektów, instruktaży, wskazówek metodycznych, a nawet prostych inspiracji, ułatwiających podjęcie działań relaksacyjnych wraz $\mathrm{z}$ wychowankami oraz 3) sygnalizowaną dominantę innych aktywności realizowanych z grupą podopiecznych (zwykle działań o charakterze plastycznym i sportowym, które w przekonaniu rozmówców stanowiły swoisty rodzaj zajęć ukierunkowany na relaks i odpręże- 
nie ${ }^{5}$. Powyższe obserwacje skłoniły autorki do dalszej pracy oraz dyskusji nad rolą relaksacji w przestrzeni edukacyjno-wychowawczej, a także stanowią główne dylematy przyświecające niniejszemu opracowaniu.

\section{Zakończenie}

Brak widoczności i popularności praktyk relaksacyjnych w przestrzeni edukacyjnowychowawczej, a także zaobserwowana luka w zbiorze metodycznych rozwiązań, zainspirowała autorki do podjęcia dyskusji na temat roli i miejsca efektywnego odprężania się w przestrzeni oddziaływań pedagogicznych. Choć wspomniane rozpoznanie opinii pedagogów i wychowawców przyjęło jedynie formę pilotażowego badania, już na tym etapie pozwoliło zaobserwować zarówno braki w wiedzy i doświadczeniu, jak i żywe zainteresowanie problematyką (zwłaszcza wśród studentów-młodych aspirujących pedagogów). Poddając analizie rzeczywistość edukacyjną, dostrzega się, że relaksacja jest często niedoceniania, a także mylona z innymi aktywnościami, których cel nie zawsze jest ukierunkowany na relaks i odprężenie. Ponownie pragniemy podkreślić, że artykuł pełni jedynie funkcję przyczynku do zgłębiania tejże problematyki, jednocześnie pozwolił zobrazować własną propozycję elastycznego i twórczego opracowywania zastanych technik. Autorki żywią nadzieję, że uwrażliwienie na potrzebę włączania zajęć relaksacyjnych w codzienność edukacyjno-wychowawczą pozwoli uniknąć nietrafionych, ryzykownych i niepożądanych sposobów rozładowania napięcia psychofizycznego wśród młodych ludzi. Wdrażane działania powinny mieć zatem charakter zarówno edukacyjny (informacyjny) - dostarczając odpowiedniej wiedzy na temat wpływu stresu na jakość życia człowieka, jak i charakter praktyczny („instruktażowy”), wyposażając wychowanków w przydatne narzędzia i sposoby radzenia sobie ze stresem.

\section{Bibliografia}

Baduń-Karolczuk E. (2013) Radzenie sobie z emocjami i stresem, „Remedium”, nr 7, s. 1-7.

Baranowska-Jojko E., Wiechuła A., Fronczak A. (2018) Arteterapia w przedszkolu. Scenariusze zajęć, Warszawa, Wydawnictwo Forum Raabe.

Cungi Ch., Limousin S. (2010) Jak się relaksować stosujq̨c odpowiedniq metodą, Warszawa, Wydawnictwo Czarna Owca.

\footnotetext{
${ }^{5}$ Wszystkie materiały pozyskane w ramach spotkań z praktykami i studentami są w posiadaniu autorek artykułu. Przyjęły one formę zbioru notatek tematycznych.
} 
Daszykowska J. (2009) „Shopping” jako nowy sposób spędzania czasu wolnego w: Czas wolny. Przyszłość - teraźniejszość - przyszłość, J. Daszykowska, R. Pelczar (red.), Stalowa Wola, Wydawnictwo Katolickiego Uniwersytetu Lubelskiego, s. 193-201.

Furmanik-Celejewska A. (2016) Muzolandia przedszkolaka. Scenariusze zajęć dla nauczycieli rytmiki i wychowania przedszkolnego, Warszawa, Wydawnictwo Difin.

Gąsienica-Szostak A. (2014) Muzykoterapia w rehabilitacji i praktyce, Warszawa, Wydawnictwo Lekarskie PZWL.

Gładyszewska-Cylulko J. (2007) Wspomaganie rozwoju dzieci nieśmiałych poprzez wizualizację i inne techniki arteterapii, Kraków, Oficyna Wydawnicza „Impuls”.

Gładyszewska-Cylulko J. (2011) Arteterapia w pracy pedagoga. Teoretyczne i praktyczne podstawy terapii przez sztukę, Kraków, Oficyna Wydawnicza „Impuls”.

Herbert M. (2004) Rozwój społeczny ucznia, Gdańsk, Gdańskie Wydawnictwo Naukowe.

Heszen I. (2013) Psychologia stresu, Warszawa, Wydawnictwo Naukowe PWN.

Jelonkiewicz I., Kosińska-Dec K. (2004) Spostrzegane zasoby, a doświadczanie stresu rodzinnego i szkolnego wśród młodzieży w: Rozwój, zdrowie, choroba. Aktualne problemy psychosomatyki, K. Kosińska-Dec, L. Szewczyk (red.), Warszawa, Bel Studio Sp. z.o.o., s. 71-90.

Józefowski E. (2012) Arteterapia w sztuce i edukacji, Poznań, Wydawnictwo Naukowe Uniwersytetu im. Adama Mickiewicza.

Komorowska M. (2008) Radzenie sobie ze stresem a uzależnienie wśród nastolatków, „Remedium”, nr 6, s. 4-6.

Konieczna A. (2010) Biblioterapia w praktyce. Poradnik dla nauczycieli, wychowawców i terapeutów, Kraków, Oficyna Wydawnicza „Impuls”.

Konieczna E. J. (2013) Arteterapia w teorii i praktyce, Kraków, Oficyna Wydawnicza „Impuls”.

Kozdroń A. (2014) Scenariusze zajęć i zabaw dla wychowawców, pedagogów, animatorów kultury i rodziców, Warszawa, Wydawnictwo Difin.

Kulmatycki L. (1993) Stres Joga, Relaksacja. Podręcznik ćwiczeń, Wrocław, Wydawnictwo W. Bagiński i Synowie.

Kulmatycki L. (1995) Ćwiczenia relaksacyjne. Praktyczne techniki antystresowe dla dzieci i młodzieży, Warszawa, Agencja Promo-Lider. 
Kulmatycki L., Torzyńska K. (2013) Ćwiczenia relaksacji, koncentracji i medytacji, Wrocław, Wydawnictwo Akademii Wychowania Fizycznego we Wrocławiu.

Kunikowski S. (2014) Edukacja kulturalna wobec wyzwań cywilizacyjnych, „Zeszyty Naukowe WSHE, Nauki Pedagogiczne", nr 2, s. 20-25.

Lazarus R. (1986) Paradygmat stresu i radzenia sobie, „Nowiny Psychologiczne”, nr 3-4, s. 2-39.

Marek E. (2004) Arteterapia jako metoda wspomagająca pracę wychowawczq w: Sztuka $w$ edukacji i terapii, M. Knapik, W. Sacher (red.), Kraków, Oficyna Wydawnicza „Impuls”.

Marynowicz-Hetka E. (2010) Kategoria pomocy w rozwoju - analiza z punktu widzenia pedagogiki społecznej w: Rozwój i jego wspieranie w perspektywie nauk o człowieku - teoria i rozwiq̨zania praktyczne, K. Baranowicz, A. Sobczak, M. Znajmiecka-Sikora (red.), Łódź, Wydawnictwo Uniwersytetu Łódzkiego, s. 9-18.

Mularska M. (2001) Uczeń i stres, „Lider”, 1 (131), s. 9-10.

Nikitorowicz J. (2003) Typy tożsamości człowieka w społeczeństwie zróżnicowanym kulturowo, „Chowanna”, nr 1, s. 50-66.

Ogińska-Bulik N. (2016) Wiem co jem - psychologia nadmiernego jedzenia i odchudzania się, Łódź, Wydawnictwo Uniwersytetu Łódzkiego.

Olechnicki K. (2009) Fotoblogi, pamiętniki z opcja przekazu. Fotografia i fotoblogerzy w kulturze konsumpcyjnej, Warszawa, Wydawnictwo Akademickie i Profesjonalne.

Pracojło-Maj A. (2015) Cyberprzemoc jako zagrożenie dla rozwoju współczesnej młodzieży w: Zagrożenia dla rozwoju współczesnej młodzieży, W. Walc (red.), Rzeszów, Wydawnictwo Uniwersytetu Rzeszowskiego, s. 94-101.

Przetacznik-Gierowska M., Tyszkowa M. (2018) Psychologia rozwojowa człowieka, Tom I. Zagadnienia ogólne, Warszawa, Wydawnictwo Naukowe PWN.

Pyżalski J. (2012) Agresja elektroniczna i cyberbullying jako nowe ryzykowne zachowania młodzieży, Kraków, Oficyna Wydawnicza „Impuls”.

Rozmysłowicz P. (2006) Arteterapia jako metoda korygowania zaburzeń emocjonalnych w: Wczesna edukacja dziecka, J. Bałachowicz, A. Kowalska (red.), Warszawa, Wyższa Szkoła Pedagogiczna Towarzystwa Wiedzy Powszechnej, s. 65-73.

Sasin M., Pikała A. (2016) Arteterapia. Scenariusze zajęć, Łódź, Wydawnictwo Uniwersytetu Łódzkiego. 
Sędłak D., Wycech B. (2014) Zabawy relaksacyjne i wyciszające na zajęciach terapeutycznych, Warszawa, Wydawnictwo Raabe.

Siek S. (1990) Treningi relaksacyjne, Warszawa, Wydawnictwo Akademii Teologii Katolickiej.

Stegemann T., Hitzeler M., Blotevogel M. (2013) Arteterapia dla dzieci i młodzieży, Gdańsk, Wydawnictwo Harmonia.

Suchodolski B. (1990) Horyzonty edukacji kulturalnej. Wychowanie mimo wszystko, Warszawa, Wydawnictwo Szkolne i Przedszkolne.

Szkudlarek T. (1999) Media. Szkice z filozofii i pedagogiki dystansu, Kraków, Oficyna Wydawnicza „Impuls”.

Szulc W. (2012) Arteterapia: narodziny idei, ewolucja teorii, rozwój praktyki, Warszawa, Wydawnictwo Difin.

Szyszko-Bohusz A. (1979) Funkcja ćwiczeń odprężających w nowoczesnym systemie kształcenia, Kraków, Wydawnictwo Ossolineum.

Talik E. (2011) Specyfika stresu szkolnego i strategie radzenia sobie z nimi przez młodzież w wieku dorastania, „Horyzonty Psychologii”, t. 1/1, s. 127-137.

Tyszkowa M. (1986) Zachowanie się dzieci szkolnych w sytuacjach trudnych, Warszawa, PWN.

Witkin G. (2000) Stres dziecięcy. Czym jest, jak się przejawia, jak mu zaradzić, tłum. N. Radomski, Poznań, Dom Wydawniczy REBIS.

Zubrzycka-Maciąg T. (2016) Wychowanie w praktyce szkolnej. Scenariusze godzin wychowawczych dla klas IV-VI szkoły podstawowej, Warszawa, Wydawnictwo Difin. 